\title{
Fabrication and Performance Evaluation of Lightweight Eco-friendly Construction Bricks Made with Fly Ash and Bentonite
}

\author{
Shimol Philip, Ajin A., Farsana Shahul., Lenin Babu, Tina J.
}

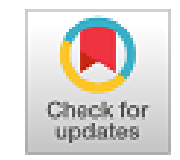

\begin{abstract}
Brick is one of the foremost extensively used construction materials for masonry purpose. Emphasizing the possibility to convey imperative effect against India's present-day lodging and industrial waste concerns are of paramount importance. This could be achieved by fabricating sustainable products using industrial wastes. Alkali-activated products are assumed to be eco-friendly and economical, leading to Portland cement-free products. This project work is an attempt to discover an eco-friendly brick for construction purposes by totally replacing the normal brick components by wastes from many industries. For the investigation purpose, we developed geopolymer bricks by utilizing fly ash as the binder, foundry sand as the fine aggregate, bentonite as an additive for improving its properties and finally the alkaline arrangement (a blend of $\mathrm{NaOH}$ and $\mathrm{Na}_{2} \mathrm{SiO}_{3}$ ). Fly ash combines with alkalis such as Sodium Hydroxide (NaOH) and Sodium Silicate $\left(\mathrm{Na}_{2} \mathrm{SiO}_{3}\right)$ creating an alumino-silicate gel, that shows properties similar to that of cement and it can be used as the environment-friendly binding material. The design mix proportions of the current work are 0.54:0.44:0.04 (fly ash: foundry sand: bentonite), solutions to fly ash ratio is 0.5 and the ratio of $\mathrm{Na}_{2} \mathrm{SiO}_{3}$ to $\mathrm{NaOH}$ is 1.5. The basic characteristics of bricks such as compressive strength, water absorption capacity, density, soundness, efflorescence, and hardness were tested. It attains a compressive strength value ranging between 6-25Mpa, water absorption value in between $5-12 \%$ and also the developed bricks were light in weight. Also, the final conclusions were drawn after comparing the test results with other geopolymer bricks and clay burnt bricks. Geopolymer bricks seem to be incredibly beneficial as they will amalgamate a large quantity of industrial wastes. The utilization of waste raw materials (except for alkaline activator solution) resulted in a substantial reduction in the estimated production cost of the bricks.
\end{abstract}

Key Words: Fly ash, Foundry sand, Bentonite, Sodium Hydroxide (NaOH) and Sodium Silicate $\left(\mathrm{Na}_{2} \mathrm{SiO}_{3}\right)$

Revised Manuscript Received on October 30, 2019.

* Correspondence Author

Shimol Philip*, B. Tech graduates, Department of Civil Engineering, VAST TC, Kilimanoor, Kerala. Email: shimolphilip16@gmail.com

Ajin A., B. Tech graduates, Department of Civil Engineering, VAST TC, Kilimanoor, Kerala Email : ajinat1999@gmail.com

Farsana Shahul, B. Tech graduates, Department of Civil Engineering, VAST TC, Kilimanoor, Kerala. Email: farsanashahul97@gmail.com

Lenin Babu, Assistant Professor, Department of Civil Engineering, VAST TC, Kilimanoor, Kerala. Email: lenin.babu@vidyatcklmr.ac.in

Tina J., Assistant Professor, Department of Civil Engineering, VAST TC, Kilimanoor, Kerala. Email: tina.j@vidyatcklmr.ac.in

(C) The Authors. Published by Blue Eyes Intelligence Engineering and Sciences Publication (BEIESP). This is an open access article under the CC BY-NC-ND license (http://creativecommons.org/licenses/by-nc-nd/4.0/)

\section{INTRODUCTION}

All through the years, there has been a considerable development in the brick manufacturing industry because of an up swinging requisite for dwelling and infrastructure in developing nations. Over and above, swift industrial development in these countries has created a substantial quantity of waste that has a negative impact on the environment. The increasing demands for infrastructure and environmental pollutants have indeed necessitated utilizing these wastes as raw materials for the manufacturing of bricks [1]. Moreover, the usage of cement or different chemical binders will increase the greenhouse gases; since a normal cement manufacturing unit produces an embodied carbon of $0.95 \mathrm{~kg}$ carbon dioxide per $\mathrm{kg}$ of cement that is produced $[2,3]$. Therefore, the recent trends of researches are finding its way towards experimentation of eco-sustainable alkaliactivated bricks. It renders the likelihood of using 100\% waste materials as the base material, which gives rise to ordinary Portland cement-free bricks or hybrid cement. Activation of aluminium oxide and silicate solids by alkaline liquids ends up in the formation of geopolymeric gel pursued by setting and solidifying at a specific curing condition [4] Geopolymer is a mineral polymer that outcomes from the combination of many small mineral molecules into a covalently bonded network i.e. geopolymer synthesis [4]. Thus, the geopolymerization (alkali activation) process is simply the synthesis of alumino-silicates in strong alkaline media. Many studies have proven that, in order to get an alkali-activated product, three main constituents are required: raw material (source of alumina and silicates), filler and alkali-activators. The distinctive raw materials utilized for alkali activation are - industrial wastes or by-products such as fly ash (FA), boiler ash (BA), rice husk ash (RHA), mining waste tailing (MT), ground granulated blast furnace slag (GGBS), sugarcane bagasse ash (SCBA), and fillers like stone dust, kaolinite, stone dust, lateritic clay and many more. Hydroxides and silicates of alkali (to be specific $\mathrm{Ca}^{2+}, \mathrm{Li}^{+}$, $\mathrm{Na}^{+}, \mathrm{K}^{+}$,) are the foremost extensively used alkali-activators. The implementation of alkali-activated geopolymer bricks or masonry blocks in the field construction proved to be eco-sustainable, efficient and cost-effective.

Published By:

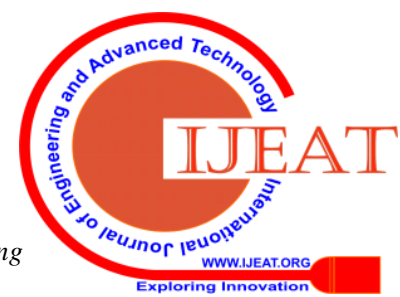




\section{Fabrication of Lightweight Geopolymer Bricks Using Bentonite as Additive and a Comparative Study on the Characteristics of Different Geopolymer Bricks}

Bhasker T. et al. [5] did investigations to examine the fabrication of geopolymer blocks utilizing fly ash and quarry dust. As the level of fly ash decreases below quarry dust, water absorption, and compressive quality increases. Preetinder Singh et al. [6] carried out an experiment on geopolymer blocks utilizing fly ash and foundry sand. This investigation depends on the fabrication of geopolymer blocks utilizing fly ash, mineral material, foundry sand, and alkaline activators. The respective work is done by developing a geopolymer brick having a size of $230 \times 110 \times 75 \mathrm{~mm}$ with substitution of river/manufactured sand by the mixture of foundry sand and mineral material. $\mathrm{T}$. Subramani et al. [7] cast bricks using fly ash, eco-sand, and alkaline activators and the solid to liquid ratio was $3: 1$. Then obtained brick specimens with low density (lightweight), high compressive strength (6-25Mpa), poor water absorption (5-12\%) and high flexibility and also the bricks were tested for its color, dimension, and efflorescence value. Banupriyal et al. [8] did examinations to think about the conduct of eco-friendly blocks utilizing fly ash and Ground Granulated Blast Furnace Slag (GGBS). The test outcomes affirmed that geopolymer block utilizing $65 \%$ fly ash and $35 \%$ of GGBS develops great compressive quality. S. R. Sanjaiyan et al. [9] cast geopolymer blocks utilizing fly ash and dyeing sludge. Dyeing sludge is the final residue formed due to the chemical treatment of dyeing industrial effluent. Blocks of size 230 x 115x $75 \mathrm{~mm}$ were arranged and restored under oven at $110^{\circ} \mathrm{C}$ for 24 hours. The high value of compressive strength and lower water absorption capacity is obtained at the mix proportion of 90:10 (fly ash: dyeing sludge).

The inference from the Literature Study indicates big importance for geopolymer bricks in the near future, in the construction sector. The geopolymer brick specimens have a compressive strength value ranges in between $6-25 \%$ and the percentage of water absorption ranging between $5-12 \%$. For the manufacturing of geopolymer brick, an environmentally friendly and eco-sustainable binder is used instead of cement. The current analysis briefs the properties of alkali-activated bricks that are fabricated from numerous raw materials such as fly ash, foundry sand, bentonite, and alkali-activators. This paper also evaluates the influence of bentonite as an extra additive on the characteristics of the brick. The paper deals with the fabrication of geopolymer brick using foundry sand and bentonite and the experimental analysis to determine the characteristics such as compressive strength, water absorption, the density of brick, efflorescence, sound, and hardness. Finally, the test results are compared with other geopolymer bricks, fly-ash brick, and clay brick. Also, the density of geopolymer brick is compared with the conventionally using other building bricks.

\section{EXPERIMENTAL PROCEDURES}

\subsection{Raw Materials For Bricks}

Four raw materials were used in this work:
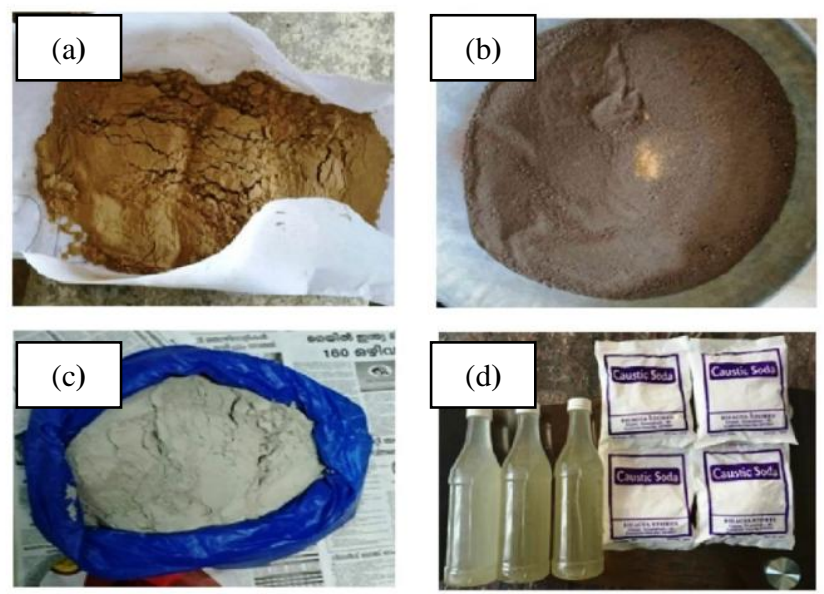

Fig. 1: a) Flyash b) Foundry sand c) Bentonite d) Sodium Hydroxide and Sodium Silicate

2.1.1 Fly ash: Flyash is a waste from thermal power plant units. It is rich in siliceous and aluminous material and a lot of progressively different constituents. Fundamental constituents of flyash are Silicon dioxide (25-60\%), Aluminum oxide (10-30\%), Ferric oxide (5-25\%) and Calcium oxide. Class F flyash is kind of flyash in which the absolute level of these three constituents are greater than or equal to $70 \%$ and calcium oxide is under $10 \%$. Fly ash is finely divided material and hence has more surface area to react with chemicals which thereby improves its pozzolonic activity and thereby increases its cementitious properties.

2.1.2 Foundry sand: Foundry sandis high-class silica sand and it is a side-effect of ferrous and non-ferrous metal casting industries. This sand has been utilized for trim material as a result of its warm conductivity.

2.1.3 Bentonite: It is a kind of clay formed by the change of glass particles from volcanic cinder. Bentonite blended with foundry sand gives good moulding property to brick and is utilized as a binder. It can be used as a binding material for many casting works and has properties such as viscosity and plasticity.

2.1.4 Alkaline Solution: The soluble arrangement is a consolidated blend of Sodium hydroxide $(\mathrm{NaOH})$ or Potassium hydroxide $(\mathrm{KOH})$ and Sodium silicate otherwise called water glass $\left(\mathrm{Na}_{2} \mathrm{SiO}_{3}\right)$. The sodium hydroxide arrangement can be set up by dissolving the pellets of $\mathrm{NaOH}$ in one liter of water for various molar concentrations by various mass. Both the arrangements should be premixed of 24 hours before use. They have a soapy or slippery feel to touch and they are also used in products such as soap, medicines, etc.

\subsection{Characterization of Raw Materials}

The design mix ratios are referred from the research done by Dr. D. S. Ramachandra Murthy. According to the reference, $54 \%$ of fly ash, $44 \%$ of foundry sand, $4 \%$ of bentonite and a $10 \mathrm{M}$ solution is used for the final experimental work. The ratio of alkaline solution to fly ash is 0.5 and the ratio of $\mathrm{Na}_{2} \mathrm{SiO}_{3}$ to $\mathrm{NaOH}$ is 1.5. A mould having a size of $22.5 \mathrm{~cm} \times 10.5 \mathrm{~cm} \times$ $7.5 \mathrm{~cm}$ is used for the casting of brick specimens.

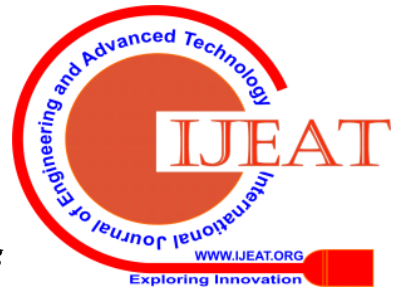



specimens.

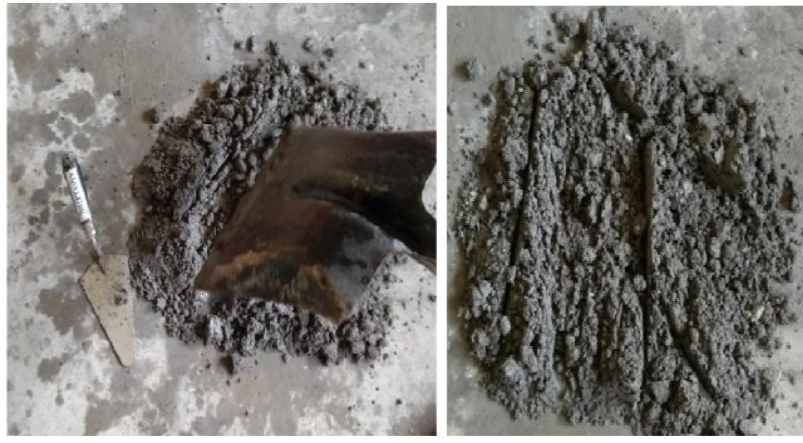

Fig. 2: Mixing of materials

\subsection{Preparation of Geopolymer Brick Samples}
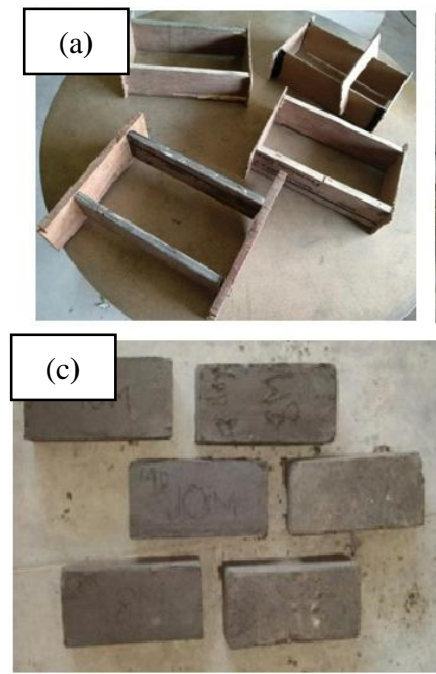

Fig. 3: a) Brick mould Demoulded bricks
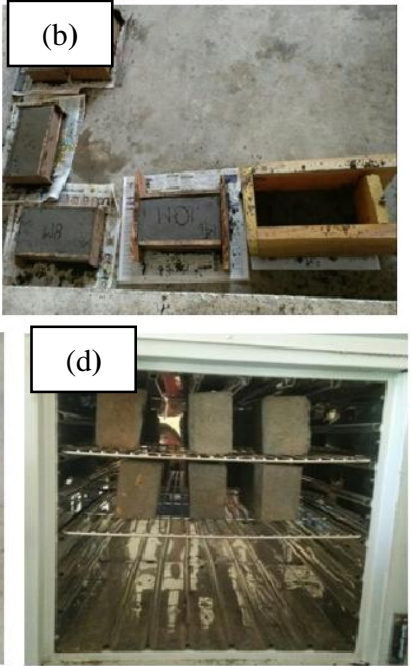

b) Casting of bricks c) d) Oven drying
The block shape having a size of $22.5 \times 10.5 \times 7.5 \mathrm{~cm}$ was made utilizing plywood. The flyash, foundry sand, and bentonite were blended physically in a holder and then, the premixed alkali arrangement was added to set up the geopolymer block. The blended materials were put in $22.5 \times 10.5 \times 7.5 \mathrm{~cm}$ shape in three layers, and each layer was compacted by giving 25 blows with a $16 \mathrm{~mm}$ diameter tamping rod. Subsequent to casting the samples, they were kept in rest period under room temperature for 3 days. The geopolymer block were demoulded after the required time period and after that, the demoulded brick specimens were kept under the oven for about 24 hours for a higher temperature range of $110^{\circ} \mathrm{C}$. The blocks were then permitted to cure under room temperature for the coming days.

\subsection{Testing And Measurements}

Compressive strength, water absorption, efflorescence, density, hardness and the sound test was performed for all

The compressive strength of the prepared geopolymer bricks was determined according to IS 3495 (Part-2) under standard loading condition of $14 \mathrm{~N} / \mathrm{mm}^{2}$ per minute utilizing a compression testing machine. Compressive strength on the day after oven drying, $7^{\text {th }}, 14^{\text {th }}$ and $28^{\text {th }}$ day was noted. The minimum compressive strength required for a good building brick as per IS code is $3.5 \mathrm{~N} / \mathrm{mm}^{2}$.

The degree of compactness of bricks can be obtained by water absorption test, as water is absorbed by pores

in bricks. The water absorption by bricks increases with an increase in the number of pores.

The standard equation for finding water absorption in \% is given as

Water absorption \% by mass, $\mathrm{W}=\frac{M_{2}-M_{1}}{M_{1}} \times 100$

Where,

\section{$\mathrm{M}_{1}$ - Dry weight in $\mathrm{kg}$ \\ $\mathrm{M}_{2}$ - Wet weight in $\mathrm{kg}$}

Density is described as the ratio between the dry weight and the volume of the brick, measuring the proportion of matter found in the volume. As the denser the brick is, the better its mechanical and durability properties are. Low density or lightweight bricks have great advantages especially in construction field including lower structural dead load, easier handling, lower transport costs, and lower thermal conductivity.
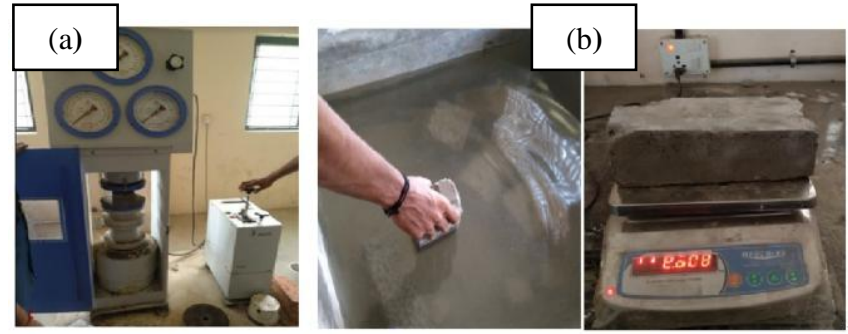

Fig. 4: a) Compressive strength testing machine b) Immersion of brick in water c) Water absorption test 2.5 Comparative Evaluation of Geopolymer Bricks

The developed geopolymer brick using foundry sand and bentonite as additive were compared with other geopolymer brick, clay brick, and fly-ash brick on the basis of various brick properties such as compressive strength, water absorption and density of brick. The four main ingredients required for clay brick making includes suitable clay and sand, water, fuel, and manpower. Suitable soils contain 25 to $50 \%$ clay and silt and 50 to $75 \%$ coarser material as determined by the simple sedimentation test. The soil must be well graded. The clay is obtained by chipping it out of a clay bank and when necessary, mixing it with sand to a mixture that will not crack during drying. Water is gradually added to make the clay plastic.

Main ingredients required for flyash brick include flyash, water, quicklime or lime sludge, cement, aluminum powder, and gypsum. The raw materials are blended in desired proportions in a pan mixer for 4-5 minutes and compressed. They undergo curing for a minimum of 14 days and are then air-dried for 7 days.

The main components of geopolymer brick using quarry dust are the mixture of flyash and alkaline solution as the binder, quarry dust as fine aggregate. The ratio flyash to quarry dust by mass is varied from $1: 2$ to $1: 5$ ratio and the ratio of the chemical were 2.5:1 for liquids. The flyash-based geopolymeric masonry bricks were cured in the oven at $60^{\circ} \mathrm{C}$ for 24 hours. The main components of geopolymer brick using dyeing sludge are a combination of flyash and alkaline activator solution as the binder, dyeing sludge as fine aggregate.

Published By:

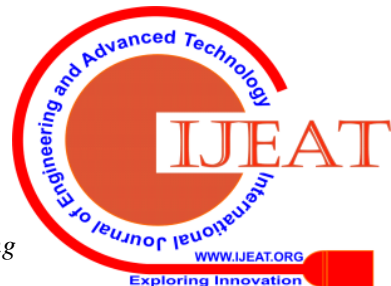




\section{Fabrication of Lightweight Geopolymer Bricks Using Bentonite as Additive and a Comparative Study on the Characteristics of Different Geopolymer Bricks}

The dyeing sludge is the final residue formed due to the chemical treatment of dyeing industrial effluent. The bricks were cast in the fly ash to dyeing sludge ratios of 90:10, 80:20, 70:30, 60:40, and 50:50 and tested for various properties to get the results.

\section{RESULT AND DISCUSSION}

\subsection{Compressive Strength Test Results}

From the graph and table showed above, it can be seen that the compressive strength increases with an increase in age.

It is due to the general fact that the compressive strength increases with increase in the curing period due to the improvement in the polymerization process. Also due to the fine size of fly ash, more surface area will be available to react with the chemicals, thus more will be the pozzolanic activity of fly ash and increased pozzolanic activity leads to increase in compressive strength.

3.2 Water Absorption Test Results: From the water absorption test on geopolymer brick, the percentage of water absorption was found to be $8.47 \%$. It can be concluded that these types of bricks have less water absorption capacity due to the limited number of pores in these bricks and hence more compact structure can be obtained. For normal clay brick, \% water absorption lies in between 20-25 \%.
3.3 Sound Test Results: For a good building brick, it produces a clear ringing sound when two bricks strike each other. Here, our brick sample produces a clear ringing sound when they struck each other. If a dull sound is produced when the two bricks strike each other, it is not suitable for building purposes.

3.4 Hardness Test Results: When the surface of the brick is scratched using the fingernail, no nail mark is formed on the surface. For a good building brick, there should not be any scratch mark on the brick; hence we can say that it is ideal for construction purposes because the brick is hard enough.

3.5. Efflorescence Test Results: A slight amount of white powder is formed on the brick surface. It is ultimately due to the presence of alkali and lack of burning of bricks.

3.6. Density: The density was determined geometrically as the quotient of the mass of the brick by its volume. The standard value of density for ordinary burned clay brick is $2400 \mathrm{~kg} / \mathrm{m}^{3}$ and that of the developed brick samples has a density value of $1226.57 \mathrm{~kg} / \mathrm{m}^{3}$ is obtained. It means that geopolymer bricks are lighter in weight than normally burned clay brick. The weight loss in geopolymer brick is due to the combustion of carbon and moisture evaporation.

Table I: Compressive Strength for developed bricks

\begin{tabular}{|c|c|c|c|c|}
\hline SI .No & Time (Days) & $\begin{array}{c}\text { Load At } \\
\text { Failure(N) }\end{array}$ & $\begin{array}{l}\text { Size of Brick } \\
\left(\mathrm{mm}^{2}\right)\end{array}$ & $\begin{array}{c}\text { Compressive Strength } \\
\text { (Мра) }\end{array}$ \\
\hline 1 & After oven drying & 20000 & $225 \times 105$ & 0.85 \\
\hline 2 & $7^{\text {th }}$ & 40000 & $225 \times 105$ & 1.69 \\
\hline 3 & $14^{\text {th }}$ & 90000 & $225 \times 105$ & 3.81 \\
\hline 4 & $28^{\text {th }}$ & 140000 & $225 \times 105$ & 5.93 \\
\hline
\end{tabular}

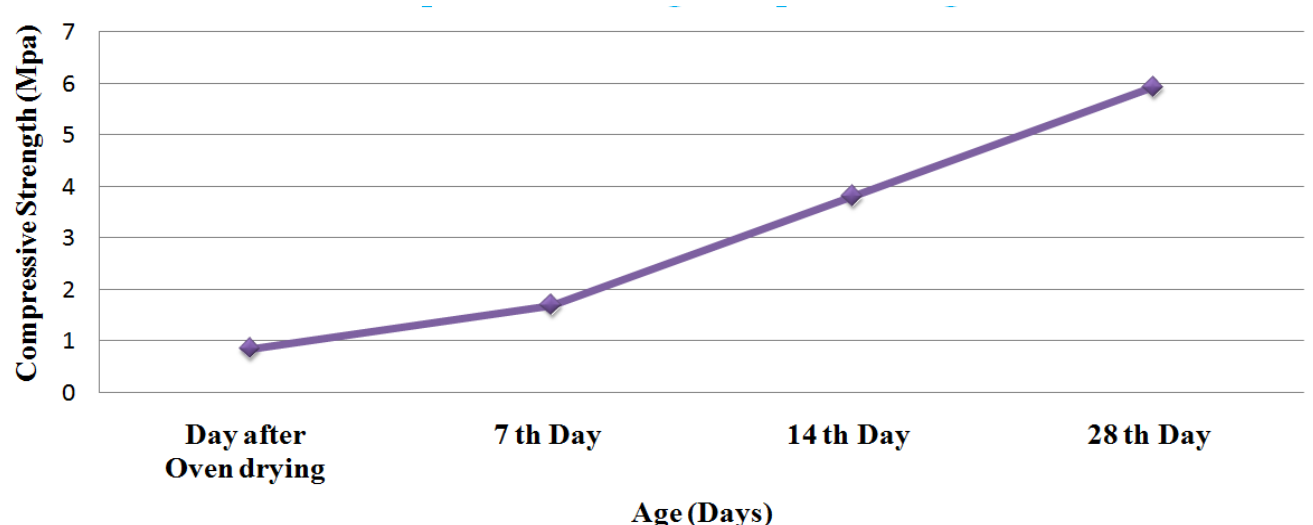

Fig. 5: Variation of compressive strength for different curing periods 
3.7 Comparative Evaluation of Prepared Sample Bricks with Fly Ash Brick, Clay Brick and Other Geopolymer Bricks

Table II: Characteristics of different bricks

\begin{tabular}{|c|c|c|c|c|c|c|}
\hline $\begin{array}{l}\text { SI. } \\
\text { No. }\end{array}$ & Property & $\begin{array}{l}\text { Clay } \\
\text { brick }\end{array}$ & $\begin{array}{l}\text { Fly ash } \\
\text { brick }\end{array}$ & $\begin{array}{l}\text { Geopolymer brick } \\
\text { using quarry dust } \\
(1.2: 0.3)\end{array}$ & $\begin{array}{l}\text { Geopolymer } \\
\text { brick using } \\
\text { dyeing } \\
\text { sludge(90:10) }\end{array}$ & $\begin{array}{l}\text { Geopolymer brick } \\
\text { using foundry sand } \\
\text { and bentonite }\end{array}$ \\
\hline 1 & $\begin{array}{c}\text { Compressive } \\
\text { Strength (Mpa) }\end{array}$ & 3.5 & $7-10$ & $24.5[5]$ & $1.96[9]$ & 5.93 \\
\hline 2 & $\begin{array}{c}\text { Water absorption } \\
(\%)\end{array}$ & $20-25$ & 14 & $14.9[5]$ & $18.12[9]$ & 8.47 \\
\hline 3 & Density $\left(\mathrm{kg} / \mathrm{m}^{3}\right)$ & 2400 & 1850 & $1740[5]$ & 1461.87 [9] & 1226.57 \\
\hline
\end{tabular}

A comparative study on the basic properties of geopolymer bricks with that of other geopolymer bricks, clay brick and fly ash bricks are discussed in the above tabular column (table 2) and the graphs are shown below (fig.6,7,8).

From the fig.6, it can be seen that the high value of compressive strength is obtained for geopolymer bricks using quarry dust and the least value is for clay brick. In clay bricks, the compressive strength decreases with increasing the porosity and also with the clay composition and firing.
In geopolymer bricks, the reaction between fly ash and alkaline activator solution increases with the curing period. Therefore the compressive strength increases with the curing period due to the improvement of the polymerization process. The compressive strength value of geopolymer bricks ranges in between 6-25Mpa and a value in between these ranges can be obtained for geopolymer brick with quarry dust as fine aggregate.

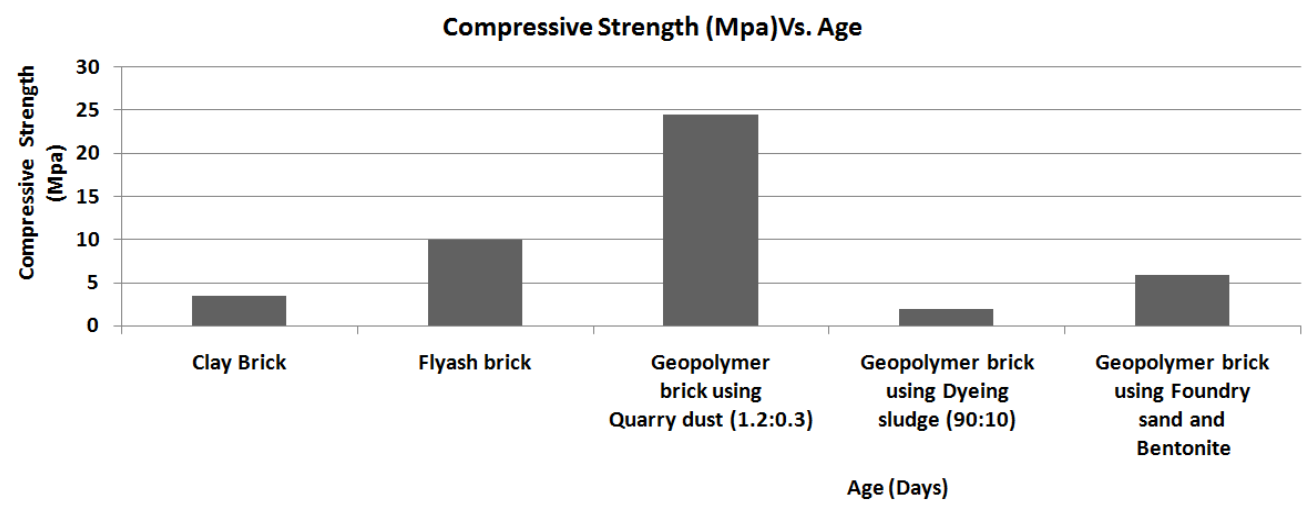

Fig. 6: Comparative evaluation of compressive strength on different bricks [5, 9]

From the fig.7 and fig.8, it can be seen that the geopolymer brick using foundry sand and bentonite has obtained the least water absorption value and density. Bentonite is a good water reducer, has ultra-fine size, sticky property and dry bonding strength. Due to these reasons, the water absorption value lies in between the standard range of geopolymer brick that is $5-12 \%$. A density value of 1226.57 $\mathrm{Kg} / \mathrm{m}^{3}$ is obtained. It is due to the combustion of carbon and moisture evaporation

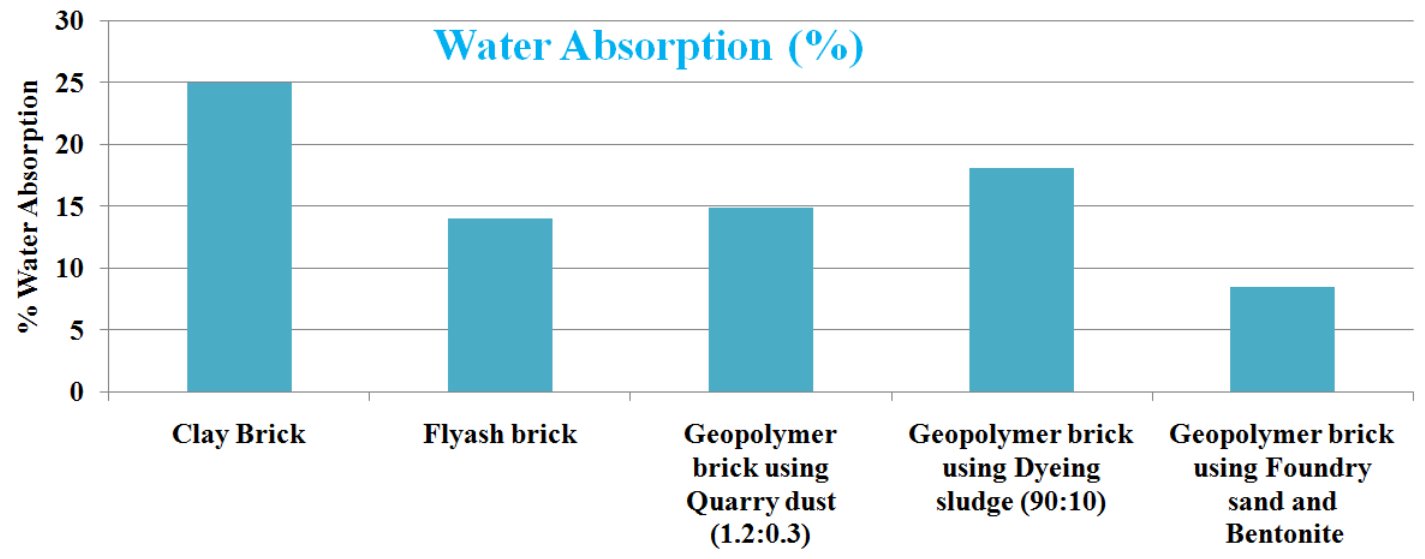

Fig. 7: Comparative evaluation of water absorption on different bricks [5, 9] 
Fabrication of Lightweight Geopolymer Bricks Using Bentonite as Additive and a Comparative Study on the Characteristics of Different Geopolymer Bricks

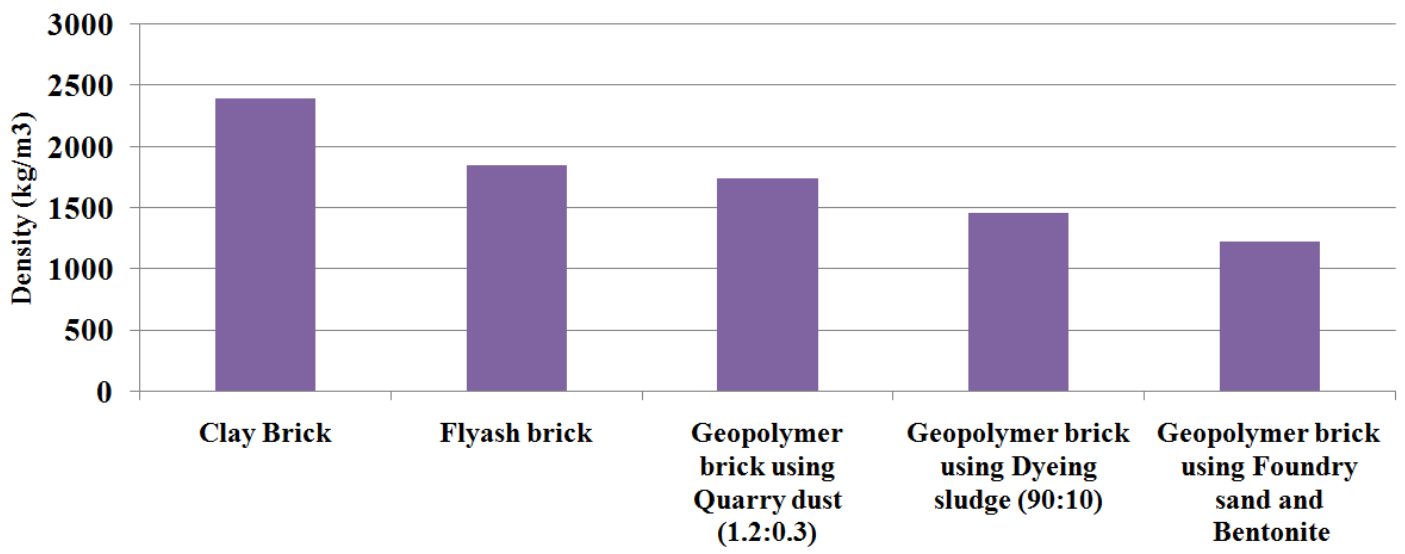

Fig. 8: Comparative evaluation of density on different bricks [5, 9]

From the fig.9, it can be concluded that the geopolymer brick using bentonite is light in weight when comparing with other conventionally using building bricks.

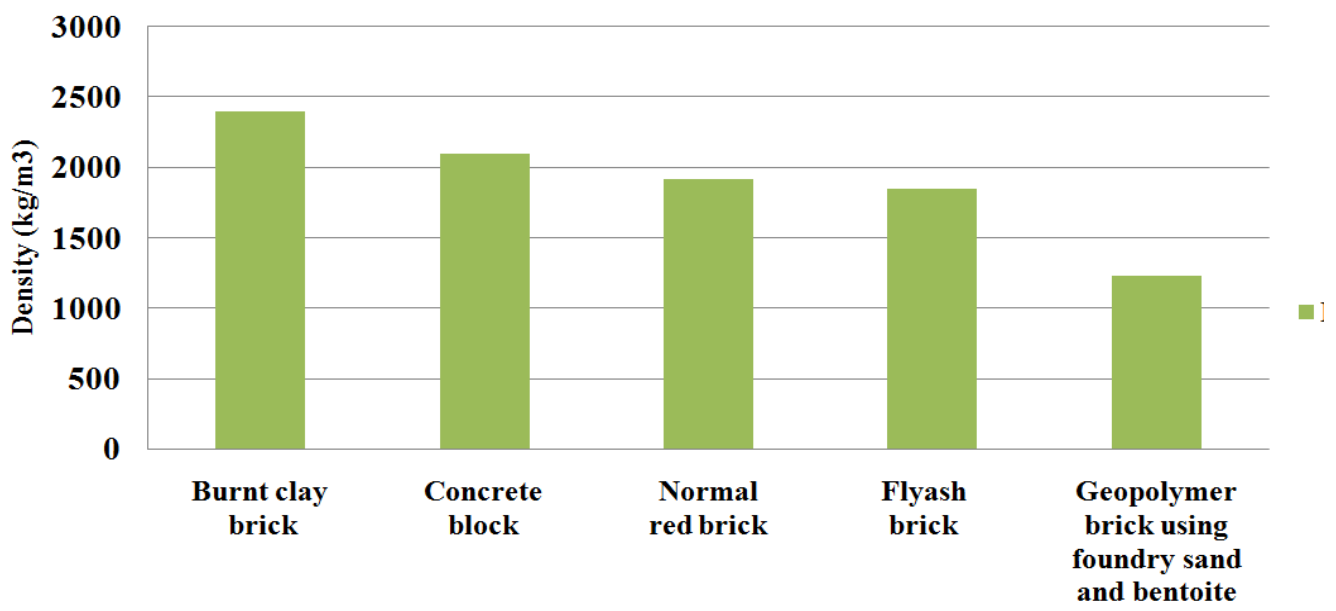

Fig. 9: Characterisation of density for different brick masonry

\section{CONCLUSIONS}

From this study, we have epitomized various advantages that geopolymer bricks hold over normal clay bricks. Using this brick in the construction field, waste materials such as fly ash, foundry sand, and bentonite can be effectively used. Thus, the amount of waste disposing on land can be reduced which in turn can save the environment. There are chances of emission of carbon dioxide and other greenhouse gases during the production of normal clay brick and it can be avoided by this proposed method of production. The compressive strength of geopolymer brick is normally greater than clay brick and it is in between 6 to $25 \mathrm{MPa}$. Normally a good building brick should have a compressive strength equal to or greater than 3.5MPa. Here the developed geopolymerbricks has a compressive strength value of 5.93MPa. Geopolymer bricks are lighter in weight compared to normal clay brick and it also has relatively less water absorption capacity than normal brick due to less number of pores in it and also due to its compact structure. The developed geopolymer brick obtains a water absorption value equal to $8.47 \%$. For a geopolymer brick, the water absorption rate will be in the range of $5-12 \%$, but a normal clay brick has a water absorption capacity ranges in between $20-25 \%$.
When two geopolymer bricks strike each other, it produces a clear ringing sound and no scratches are formed when the brick surface is scratched with the nail. A fly ash brick is known as geopolymer brick because of the usage of alkaline solution. When fly ash comes in contact with alkali solution it shows properties similar to cement. But this gives way to the formation of white powder on the surface of the brick, which is known as efflorescence. This is because of the presence of alkali on the surface of the brick, which ultimately leads to efflorescence.

Even though the main constituents are cheap waste materials, the alkali activators such as Sodium Hydroxide and Sodium Silicate is costly. Also, the use of chemicals during the mixing of constituents may lead to health issues such as skin problems; allergy, etc. It can be avoided by using protective measures such as gloves and masks.While comparing this developed geopolymer brick with other geopolymer brick, clay brick, and fly-ash brick, it obtains the least value for water absorption and it is light in weight. Also, it has the least density value when compared with normally using building bricks 
The prime reason that led us to choose this topic was to find an ecofriendly brick that has more compressive strength and better properties than normal clay brick. From our studies it can be concluded that the increasing need for cement can be reduced and consequently, the emission of greenhouse gases can be reduced. This is because in geopolymer brick, cement is completely replaced by fly ash and foundry sand is used instead of sand. Ultimately, the waste materials from many industries can be effectively utilized, instead of dumping or disposing it. Hence, it can be concluded that the developed geopolymer bricks are eco-friendly and eco-sustainable bricks.

\section{SCOPE OF FUTURE WORK}

This analysis can be extended to the following areas;

- Molarity of alkaline activator solution can be varied and the effect of molarity on the characteristics of bricks can be studied

- Properties of binders can be varied by using different types of wastes such as paper waste, green leaf, etc.

- Effect of temperature can be studied by burning the bricks in high temperature as other normal bricks

- The test can be conducted by using admixtures other than bentonite to study variations such as Metakaoline, Alcofine, etc.

- Effect on reinforcement can be analysed by using this type of construction material

- Curing of the brick using oven drying can be modified by increasing the drying period from 24 hours to 48 hours by keeping the temperature constant, that is at $110^{\circ} \mathrm{C}$

- User-friendly activator solutions can be developed and the way to reduce the rate of efflorescence formation can be studied

\section{REFERENCES}

1. T. Poinot, M.E. Laracy, C. Aponte, H.M. Jennings, J.A. Ochsendorf, E.A. Olivetti, Beneficial use of boiler ash in alkali-activated bricks, Resour. Conserv. Recycl. 128 (2018) 1-10, https://doi.org/10.1016/j.resconrec.2017.09.013

2. A.F. Abdalqader, F. Jin, A. Al-Tabbaa, Development of greener alkali-activated cement: utilisation of sodium carbonate for activating slag and fly ash mixtures, J. Cleaner Prod. 113 (2016) 66-75, https://doi.org/10.1016/j. jclepro.2015.12.010.

3. K. Komnitsas, D. Zaharaki, Geopolymerisation: a review and prospects for the minerals industry, Miner. Eng. 20 (2007) 1261-1277, https://doi.org/10.1016/j.mineng.2007.07.011.

4. J. Davidovits, Geopolymers - inorganic polymeric new materials, J. Therm. Anal. 37

(1991) 1633-1656,https://doi.org/10.1007/BF01912193

5. T. Bhasker, Syed Mohammed Ibrahim, R. Thriveni, D. Sreelatha, S. Bhasker, Dr. AshwinRaut; "Experimental investigation on geopolymer brick by using fly ash and quarry dust". International Journal of Advance Research, Ideas and Innovations in Technology- 2018 Volume 4, Issue 2.

6. Preetinder Singh, Dr. Sanjay K. Sharma, Mrs.Himmi Gupta, Er. Jasvir Singh Rattan- "Development of Geopolymer Bricks using Foundry Sand" International Research Journal of Engineering and Technology (IRJET) - Volume: 03 Issue: 08 |Aug -2016

7. T. Subramani, P. Sakthivel, "Experimental Investigation on Fly ash Based Geopolymer Bricks". International Journal of Application or Innovation in Engineering \& Management (IJAIEM) -Volume 5, Issue 5, May 2016.

8. C. Banupriya, Sharon John, R. Suresh, E. Divya and D. Vinitha-, Dr. Rangarajan, Dr. Sakunthala, "Experimental Investigation on Geopolymer Bricks/Paver Blocks"- Indian Journal of Science and Technology, Vol. 9(16)April 2016
9. S.R. Sanjaiyan, S. Vishnu, Dr. M.I. Abdul Aleem, "Geopolymer Bricks Using Fly Ash and Dyeing Sludge" ; Journal of Recent Activities in Infrastructure Science Volume 1 Issue 3; MAT Journals 2016.

\section{AUTHORS PROFILE}

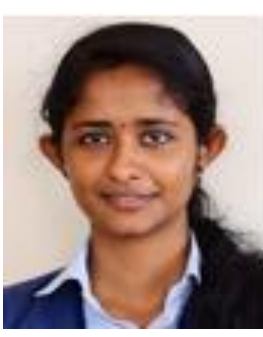

Ms. Shimol Philip, B. Tech graduate in Civil Engineering, from Vidya Academy of Science and Technology, Technical Campus, Kilimanoor, Kerala, India. Currently, she is pursuing $\mathrm{M}$. Tech in Geomechanics and Structures, First-year $1^{\text {st }}$ semester from Saintgits College of Engineering, Kottayam, Kerala. She has published several papers in various peerreviewed journals/conferences of national and international repute.

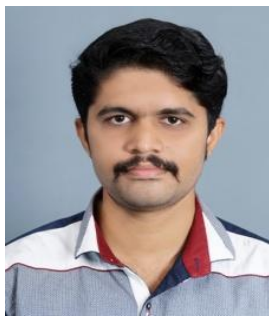

Mr. Ajin A, B. Tech graduate in Civil Engineering, from Vidya Academy of Science and Technology, Technical Campus, Kilimanoor, Kerala. Currently, he is pursuing M. Tech in Geomechanics and Structures, First - year $1^{\text {st }}$ semester from Saintgits College of Engineering, Kottayam, Kerala.

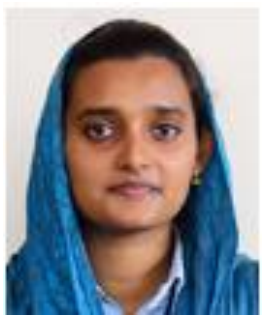

Ms. Farsana Shahul, B. Tech graduate in Civil Engineering, from Vidya Academy of Science and Technology, Technical Campus, Kilimanoor, Kerala, India. Currently, she is pursuing $\mathrm{M}$. Tech in Geomechanics and Structures, First-year $1^{\text {st }}$ semester from Saintgits College of Engineering, Kottayam, Kerala.

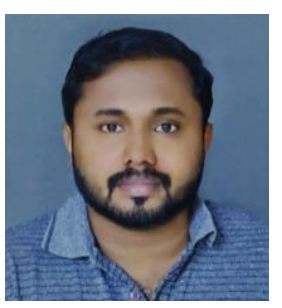

Mr. Lenin Babu presently working as Assistant Professor at Vidya Academy of Science and Technology, Technical Campus, Kilimanoor, Kerala, India. He did his M. Tech in Geoinformatics from College of Engineering Trivandrum, Kerala. He has published many papers in various reputable national/international journals and conferences

Ms. Tina J. presently working as Assistant Professor at Vidya Academy of Science and Technology, Technical Campus, Kilimanoor, Kerala, India. She completed her B.tech in Civil Engineering from TKM College of Engineering, Kollam and M. Tech in Geoinformatics from College of Engineering Trivandrum. She has published several papers in various peer- reviewed journals/conferences of national and international repute. Her research interests include Remote sensing, Geographic Information System and innovative building materials. 